\title{
The Influence of Short-term Overseas Exchange on College English Teachers' Multicultural Sensitivity
}

\author{
Yani Zong \\ Xi'an International University, Xi’an, Shaanxi, 710077
}

\begin{abstract}
Keywords: Overseas Exchange; English Teacher; Multicultural Sensitivity; English Teaching
\end{abstract}
\begin{abstract}
To cultivate the multicultural sensitivity is an important goal of college English curricular reform, and is also the inevitable requirement of quality education. Language and culture are closely tied, so are language teaching and the teaching of culture. Nowadays, with the development of globalization, different cultures of different countries conflict with each other much more, so English learning becomes more important than anytime before. At the same time, the relations of the countries in the world are becoming increasingly closer, and cultural conflicts increasingly fiercer; different races, different languages, and different cultures provide different scope of studying to learners, which inject new blood into English learning and also integrate language and culture much more. Under this background, it is necessary to combine language with culture in college English teaching, and to improve the personal comprehensive ability of English teachers. As an efficient way to experience the culture of other countries, short-term overseas exchange has become an important way for many college English teachers to improve their own abilities. Starting from the connotation of multicultural sensitivity, the writer of this thesis tries to discuss the influence of short-term overseas exchange on college English teachers.
\end{abstract}

To cultivate the multicultural sensitivity of college English teachers is not only the objective requirement of the new curricular standard, but also the necessary appeal of the current situations of economy and politics. It lets English teachers practice better personal abilities and get in touch with more different cultures; it requires all-round improvement of English teachers' professional qualities and comprehensive abilities. English teachers can get to constant self-improvement and increase their competitive advantage. English teaching is not a kind of simple language teaching that teaches words and grammars to students, but also an important way of allowing students to understand different cultures, understanding very well about the circumstances of different countries, experiencing the baptism of other excellent cultures, and feeling the charm of multiculturalism. Overseas investigation trip and short-term study aboard could have English teachers directly feel the charm of different countries and enhance their multicultural sensitivities, and get their teaching abilities improved.

\section{Connotation of Multicultural Sensitivity}

Multicultural Sensitivity means that different people who have different cultural background and multicultural awareness can avoid pragmatic errors, which are caused by the single dimensional culture, and who can use the appropriate language to express their thoughts and feelings with the people who speak different languages efficiently [1].

With the constant reform of college English teaching, the goal and position of the reform are kept being renewed. In the new standard of curricular requirement, to cultivate students' multicultural sensitivity is an important part of English curricular construction; it is also the supplement, improvement, and perfection to the goal of cultivating the talents. Therefore, it is not only necessary and urgent to carry out college English teaching reform, but also necessary to innovate the idea of English teaching so as to cultivate students' multicultural sensitivities and enhance their comprehensive abilities of English [2].

It is necessary to change the teaching model that emphasizes teaching language knowledge and aims to acquire the knowledge of words and grammar into the model that attaches importance to 
improving the multicultural sensitivities of students so as to promote teachers to organize different kinds of teaching discussion, to strengthen students' understanding about the profound cultural foundation related to the language they have learned, hence, to improve the comprehensive qualities of students. At the same time, teachers should solve the problems which have trouble English teaching for a long time such as "high scores but low ability", "mute English", "poor efficiency", and achieve the aim—quality education instead of examination education [3].

At present, with the fast integration into globalization and the reform of higher education in China, to cultivate the interdisciplinary talent has become the main goal of college English teaching; and also, to cultivate college students' multicultural sensitivities when they are in foreign countries has become the direction of foreign language teaching. All these have put forward higher requirements for college English teachers. In order to cultivate the multicultural sensitivities of students, teachers must not only have a good understanding of multicultural communicative theories and be familiar with the multicultural communicative activities of studying aboard, but also have higher multicultural communicative competences. Only on this basis could teachers teach multicultural communicative competences that they have studied and experienced aboard to their students well in class.

\section{The Influence of Short-term Overseas Exchange to College English Teachers' Multicultural Sensitivities.}

To an independent country, culture is not only the sediment of its history, but also the foundation of its development in future, and is the embodiment of its soft power and comprehensive national strength. Culture never excludes any of language, humanity, customs, history, and ideology; culture is not only abstract but idiographic. Therefore, from the dimension of culture, to improve teachers' multicultural sensitivities is a necessary way to correctly understand the connotation of the culture. To cultivate the sensitivities, learners could start from a country's vocabulary and language, its culture and history, and the practical communication. Vocabulary and language are the most important characteristics of a country. In a language of a country, vocabulary is its soul to some extent, it is the direct expression of the culture. Therefore, to strengthen the study of vocabulary and to cultivate the multicultural sensitivity are the key factors that can influence students' study of relevant languages directly and rapidly, and it is the best method of improving language abilities. Idioms, which are full of national characteristic and flavor, are a kind of cultural embodiment, and the essence of the cultural development [4]. To introduce idioms into teaching can not only have the students feel the charm of the language and culture, but also help students fast understand the culture of the country to improve their study efficiency. When teachers are teaching, they should teach the extensions of the words to the students. Take the idiom for example, what kind of spirit it expresses in foreign culture? What story is it related to? And what kind of wisdom it expresses? At the same time, teachers should properly guide students to be aware of cultural differences. In English learning, all the social etiquettes and customs of western countries need to be known in order to avoid some awkward situations caused by cultural differences. Short-term overseas exchange can allow teachers to come into close contact with foreign daily life, and then find out the genuine knowledge by practices.

As the soul, teachers not only are the transmitters who teach knowledge to their students and the students' guiders in life, but also their example in the daily study. Teachers' teaching abilities, English attainments, and multicultural sensitivities directly determine the students' English learning abilities, and also determine the training effects of the students' multicultural sensitivities in English [5]. During the cultivation of the multicultural sensitivities of the students, the teachers' teaching abilities are the key factors, how to enforce the teachers' controlling abilities in class, how to recompose and teach the different cultures, and how to select the good teaching materials and teaching resources for the students study well, these require the teachers should have higher career qualities and higher professional abilities in order to set up a good example to the students, give the students excellent lessons, solve the problems of the students, and control the process of the class correctly. Therefore, to cultivate the students, the teachers should do better, should improve their 
overall abilities in order to ensure the teaching quality and teaching efficiency. While the short-term overseas exchange could let the teachers totally understand the realistic conditions of English culture, it is not only stay in the textbook, but let the students feel the real multicultural charm; it also can improve the professional abilities of teachers to a large extent, the teachers could use their rich knowledge and the scientific means of teaching to achieve a higher teaching level. To the contrary side, the students could not only study efficiently, but also develop the multicultural sensitivities under the teachers' guidance. By the short-term overseas exchange, teacher also could find out their misunderstandings about the English culture, and then improve their professional abilities.

With short-term overseas exchange, teachers can not only improve their multicultural sensitivities, but also learn new teaching models and methods [6]. When studying aboard, teachers should clearly be aware of their responsibilities. On the one hand, teachers need to learn the foreign culture that can provide new thoughts to teaching activities; on the other hand, they also need to understand the importance of innovating teaching methods and combining foreign culture with native culture. After the correct understanding about the teaching circumstances, English teachers should adjust teaching contents, enrich and supply relevant knowledge, and cultivate multicultural sensitivities of students. What's more, teachers should adjust their teaching methods as well, keep up with the times, and employ appropriate teaching methods. Teachers can adopt the teaching model that compares the culture of a country with that of the other in order to have students feel the charm of the oriental culture. Students can understand traditional culture and study English more deeply by understanding the differences of the two different cultures. During this short-time overseas exchange, teachers can learn lots of teaching methods, get their horizon broadened, and then can improve their teaching models to a higher level.

\section{Conclusion}

In this global village, no country can avoid the influence from any other counterpart. In the teaching of college English, it is important to know this kind of combination and transmission of culture and cultivate the multicultural sensitivities of the teachers. In English teaching, teachers not only need to make some changes on teaching contents and models, but also ought to use some other teaching methods, enhance personal cultural ability and cultural understanding according to the objective personal conditions so as to give students a good guidance. As an important method of improving teachers' multicultural sencitivities, short-term overseas exchange could have teachers feel the charm and connotation of English culture, and learn much more English teaching methods; it also could check the knowledge of their own. Genuine knowledge comes from practice.

\section{References}

[1] Feng Wenying. Strategies on Improving the Multicultural Communicative Competence in College English Teaching Under the Background of Cultural Differences Between China and Western Countries[J]. Journal of Chifeng University (Philosophy and Social Science Edition), 2010, 02:145-146.

[2] Cui Dan. Research on the Changes of Proficiency in English of the English Teachers' Short-term Study in Canada[D]. Shanghai International Studies University, 2013.

[3] Cui Haiying, Wang Jing. The Investigation on Multicultural Sensitivities of College English Teachers in Herbei Province[J]. Journal of Hebei Normal University of Science \& Technology (Social Sciences edition), 2016,15(02):97-104.

[4] Yan Jinglan. The "Gaps" and the "Revamps" of the English Teachers' Multicultural Sensitivities[J]. Journal of Shanghai Normal University (Philosophy and Social Science), 2014, 43(01):138-145.

[5] Bai Wenxia, Cao Huishu, Zhang Wenjing. Investigation On the Cultural Statuses of the College 
English Teachers and Their Multicultural Communicative Competences----Take the College English Teachers of Handan City for Example[J]. New West (Theory Edition), 2014, (06):36+22.

[6] Wen Jinhai, Cao Wu. The vocabulary introduced stage of the college teaching under the strategy model----take the Powerpoint Courseware of 21 (st) College English (Book 2 Unit 4 Text A) for example[J]. Crazy English(Teachers), 2008,01:27-31. 